\title{
Effects of Calcium on the $\mathrm{GABA}_{A}$-Coupled $\mathrm{Cl}^{-} / \mathrm{HCO}_{3}^{-}$-ATPase from Plasma Membrane of Rat Brain
}

\author{
Sergey A. Menzikov*, Marina V. Kalinina \\ State Research Institute of General Pathology and Pathological Physiology RAS, Moscow, Russia \\ Email: "menzikov@mail.ru, , sambrainic@gmail.com
}

Received 5 April 2014; revised 10 May 2014; accepted 21 May 2014

Copyright (C) 2014 by authors and Scientific Research Publishing Inc.

This work is licensed under the Creative Commons Attribution International License (CC BY).

http://creativecommons.org/licenses/by/4.0/

cC) (i) Open Access

\section{Abstract}

The work is a study of the influence of $\mathrm{Ca}^{2+}(0.01-1 \mathrm{mM})$ on neuronal $\mathrm{Cl}^{-}, \mathrm{HCO}_{3}^{-}-\mathrm{ATPase}^{-}$complex: an enzyme that is a $\mathrm{Cl}^{-}$-pump which is functionally and structurally coupled to $\mathrm{GABA}_{\mathrm{A}}$-receptors. It is found that influence of $\mathrm{Ca}^{2+}$ on the multifunctional complex starts at concentration of $50 \mu \mathrm{M}$ and at concentration of $0.1 \mathrm{mM}$, it reduces the "basal" one and increases the $\mathrm{Cl}^{-}, \mathrm{HCO}_{3}^{-}$-stimulated $\mathrm{Mg}^{2+-A T P a s e}$ activities. GABA $(0.1-100 \mu \mathrm{M})$ activates the "basal" $\mathrm{Mg}^{2+}$-ATPase activity in the absence of calcium. The effect of GABA on the enzyme in the presence of $0.01 \mu \mathrm{M} \mathrm{Ca}^{2+}$ does not change. At the same time, $1 \mathrm{mM} \mathrm{Ca}^{2+}$ eliminates the GABA effect on the "basal" $\mathrm{Mg}^{2+}$-ATPase activity. Competitive blocker of $\mathrm{GABA}_{\mathrm{A}}$-receptors bicuculline $(5-20 \mu \mathrm{M})$ in the absence of $\mathrm{Ca}^{2+}$ ions eliminates the stimulation of the "basal" $\mathrm{Mg}^{2+}$-ATPase by anions. When $0.25 \mathrm{mM} \mathrm{Ca}^{2+}$ is added to the incubation medium the inhibitory bicuculline effect on the enzyme does not appear. We found that $0.1 \mathrm{mM} o$-vanadate (protein tyrosine phosphatase blocker) reduces the GABA-activated ATPase activity. At the same time, $0.1 \mathrm{mM}$ genistein (a protein tyrosine kinase blocker) has no effect on enzyme activity. In the presence of $\mathrm{Ca}^{2+}(0.25 \mathrm{mM})$, the effect of $o$-vanadate on the "basal" and $\mathrm{Cl}^{-}$, $\mathrm{HCO}_{3}^{-}$-ATPase activities does not appear. It is shown for the first time that high concentrations of $\mathrm{Ca}^{2+}$ prevent the action of $\mathrm{GABA}_{\mathrm{A}}$-ergic ligands on the study ATPase. It is assumed that there is the involvement of protein kinases and protein phosphatases in the modulation of the enzyme activity by calcium. The observed effect of calcium on the ATPase may play an important role in the study of the mechanisms of epileptogenesis and seizure activity.

\section{Keywords}

$\mathrm{Mg}^{2+-A T P a s e}$, Chloride, Bicarbonate, Calcium, Rat Brain Plasma Membranes, GABA ${ }_{A}$-Ergic Drugs,

\footnotetext{
${ }^{*}$ Corresponding author.
}

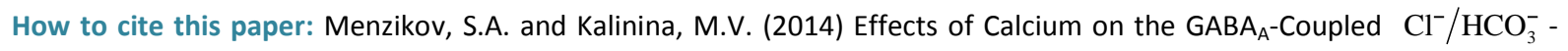
ATPase from Plasma Membrane of Rat Brain. Advances in Enzyme Research, 2, 82-91. 


\section{$o$-Vanadate, Genistein}

\section{Introduction}

$\mathrm{Cl}^{-}$-ATPase/Cl--pump in plasma membrane from various cells (including neurons) is a "molecular machine" participating in the transportation of $\mathrm{Cl}^{-}$ions against the electrochemical gradient [1] [2]. Earlier, we showed the existence of the anion-sensitive $\mathrm{Mg}^{2+}$-ATPase in developed neurons of animal brain with maximum activity in the presence of $\mathrm{Cl}^{-} / \mathrm{HCO}_{3}^{-}$ions (in the ratio of as 5:1) [3]. These data are in line with the electrophysiological studies demonstrating that $\mathrm{Cl}^{-}, \mathrm{HCO}_{3}^{-}$anions are transported through the $\mathrm{GABA}_{\mathrm{A}}$-receptor $\mathrm{Cl}^{-}$-channel in the ratio as 5:1, respectively [4]. Besides, this enzyme is functionally and structurally coupled with the $\mathrm{GABA}_{\mathrm{A}} /$ benzodiazepine receptor complex [3]. With the use of biochemical and cytochemical methods, it has been established that $\mathrm{Cl}^{-}, \mathrm{HCO}_{3}^{-}$-ATPase is localized in elements of $\mathrm{GABA}_{\mathrm{A}}$-ergic dendro-dendritic synapses [5]. The hydrolytic activity of this $\mathrm{GABA}_{\mathrm{A}}$-coupled ATPase provides the $\mathrm{Cl}^{-} / \mathrm{HCO}_{3}^{-}$-transport processes with energy and determines the direction of ion transport through neuronal membrane [6]. This conclusion is based on the following findings: the protein preferably hydrolyzes ATP and is covalently phosphorylated by ATP (directly or with the participation of protein kinase) during the transport cycle and is dephosphorylated by anions [7]. These data allow us to suppose that this is a chloride transporting ATPase: this multifunctional ATPase is a $\mathrm{Cl}^{-}$-pump participating in transporting chloride ions through the native and artificial membranes of liposomes.

Furthermore, we have found that such ATPase is involved in rat convulsant-induced seizure activity [8]. It is known that the pathogeneses of epilepsy and convulsive states are associated not only with impairment of the $\mathrm{GABA}_{\mathrm{A}}$-receptor function [9] [10] but also with calcium homeostasis [11]. It is known that the level of intracellular free calcium $\left[\mathrm{Ca}^{2+}\right]_{\mathrm{i}}$ in the nerve cells is vital for the process of neuronal transmission [12]. Moreover, cations of calcium and magnesium are required to maintain the functional activity of many receptors and enzyme systems (including the $\mathrm{GABA}_{\mathrm{A}}$-receptor) [13]. The influence of $\left[\mathrm{Ca}^{2+}\right]_{\mathrm{i}}$ on the $\mathrm{GABA}_{\mathrm{A}}$-receptors in the brain is exerted either directly through binding sites on the receptor molecule [14] or via $\mathrm{Ca}^{2+}$-dependent enzymatic processes (including protein kinases or protein phosphatases) [15]. In this regard, in the present work we have studied the influence of $\mathrm{Ca}^{2+}$ on the multifunctional ATPase activity of the neuronal membranes in the absence and in the presence of $\mathrm{GABA}_{\mathrm{A}}$-ergic ligands and blockers of protein kinases and protein phosphatases.

\section{Materials and Methods}

\subsection{Animals}

Experiments were performed on male Wistar rats weighing 180 - 200 g. Animals were maintained under standard vivarium conditions with free access to water and food. The experiment was conducted under the "Rules of work with experimental animals” FGBU “NIIOPP” RAS, which comply with the World Society for the Protection of Animals (WSPA) and the European Convention for the protection of experimental animals.

\subsection{Isolation of Plasma Membrane}

All procedures were performed at $0^{\circ} \mathrm{C}-4^{\circ} \mathrm{C}$. After decapitation of animals, the brain was isolated, homogenized in 8 vol. of ice-cold buffer solution containing $0.25 \mathrm{M}$ sucrose, $1 \mathrm{mM}$ ethylenediaminetetraacetic acid-Tris (hydroxymethyl) aminomethane (EDTA-Tris, pH 7.4), 12.5 mM N-(2-Hydroxyethyl)piperazine-N'-(2-ethanesulfonic acid) (HEPES-Tris, pH 7.4), $1 \mathrm{mM}$ phenylmethylsulfonyl fluoride (PMSF) and 50 units/ml aprotinin and centrifuged in a Beckman ultracentrifuge (SW-28 bucket rotor) at $10,000 \times \mathrm{g}$ and $4^{\circ} \mathrm{C}$ for 25 min. The supernatant was centrifuged at $100,000 \times \mathrm{g}$ and $4^{\circ} \mathrm{C}$ for $1 \mathrm{~h}$. The supernatant was discarded and microsomal fraction enriched plasma membranes (pellet) was resuspended in 1 mM EDTA-Tris (pH 7.4), 12.5 mM HEPES-Tris (pH 7.4), stirred for $15 \mathrm{~min}$ and centrifuged $(100,000 \times \mathrm{g}, 45 \mathrm{~min})$. The resulting pellets were resuspended in 12.5 $\mathrm{mM}$ HEPES-Tris ( $\mathrm{pH} 7.4$ ) and frozen at $-80^{\circ} \mathrm{C}$. This plasma membrane rich fraction was used for further measurements of the ATPase activity.

\subsection{Assay of $\mathrm{Cl}^{-}, \mathrm{HCO}_{3}^{-}$-ATPase Activity}

The enzyme preparation (20 - $25 \mu \mathrm{g}$ ) was added to $0.5 \mathrm{ml}$ incubation medium containing 12.5 mM HEPES-Tris 
buffer (pH 7.4), $1.0 \mathrm{mM} \mathrm{MgSO}_{4}, 1.0 \mathrm{mM}$ ATP-Tris, $10 \mathrm{mM} \mathrm{NaCl} / 2 \mathrm{mM} \mathrm{NaHCO}$ and $60 \mathrm{mM} \mathrm{NaNO}_{3}$ (neutral salt) to measure enzyme activity. The specific activity of ATPase was estimated from the increase in the content of inorganic phosphorus $\left(\mathrm{P}_{\mathrm{i}}\right)$ in $0.5 \mathrm{ml}$ incubation medium at $30^{\circ} \mathrm{C}$ for $30 \mathrm{~min}$. Phosphorus concentration in samples was measured by the method of Chen and expressed in $\mu \mathrm{mol} \mathrm{P}_{\mathrm{i}} / \mathrm{h} / \mathrm{mg}$ protein [16] [17]. The activity of the "basal" $\mathrm{Mg}^{2+}$-ATPase was calculated as the difference between the ATPase activities in the presence and absence of $\mathrm{MgSO}_{4}$ in the incubation medium containing $12.5 \mathrm{mM}$ HEPES-Tris buffer $(\mathrm{pH} 7.4), 1.0 \mathrm{mM} \mathrm{MgSO}$, $1.0 \mathrm{mM}$ Tris-ATP and $60 \mathrm{mM} \mathrm{NaNO}$. The $\mathrm{Cl}^{-}, \mathrm{HCO}_{3}^{-}$-activated $\mathrm{Mg}^{2+}$-ATPase was determined in the presence of $\mathrm{Cl}^{-} / \mathrm{HCO}_{3}^{-}$ions in the incubation medium containing $12.5 \mathrm{mM}$ HEPES-Tris buffer (pH 7.4), $1.0 \mathrm{mM}$ $\mathrm{MgSO}_{4}, 1.0 \mathrm{mM}$ Tris-ATP, $10 \mathrm{mM} \mathrm{NaCl} / 2 \mathrm{mM} \mathrm{NaHCO}_{3}$ and $60 \mathrm{mM} \mathrm{NaNO}_{3}$. The enzyme activation by anions was calculated as the difference between the "basal" $\mathrm{Mg}^{2+}$-ATPase activities in the presence and absence of anions (chloride/bicarbonate) in the incubation medium. The figures show values of the enzyme activity averaged from the results of at least four determinations.

\subsection{Assay of the Action of Chemicals on the ATPase Activity}

The enzyme activity in the presence of chemicals $\left(\mathrm{Ca}^{2+}\right.$, EGTA, GABA, bicuculline, picrotoxine, $o$-vanadate, genistein) was determined as described before [3]. Membrane samples were preincubated at $30^{\circ} \mathrm{C}$ for 20 min with the relevant chemical in incubation medium containing $12.5 \mathrm{mM}$ HEPES-Tris buffer (pH 7.4), $10 \mathrm{mM}$ $\mathrm{NaCl} / 2 \mathrm{mM} \mathrm{NaHCO}$ and $60 \mathrm{mM} \mathrm{NaNO}_{3}$. The reaction was started by addition of the substrate $\left(\mathrm{Mg}^{2+}\right.$-ATP) to the incubation medium.

\subsection{Chemicals}

All drugs were prepared as stock solutions in water unless otherwise stated. GABA, picrotoxin, bicuculline methochloride, $\mathrm{CaCl}_{2}$, EGTA, Tris, Hepes, $\mathrm{Na}_{2} \mathrm{ATP}$, $o$-vanadate, genistein were by Sigma-Aldrich.

\subsection{Statistics}

The data are expressed with mean \pm standard error where appropriate. The experimental data are statistically processed using one-way ANOVA test program "Statistica 7.0". Evaluation of the significance of differences was carried out at $\mathrm{p}<0.05(\mathrm{n}=4)$.

\section{Results and Discussion}

\subsection{Detection and $\mathrm{Ca}^{2+}$ Effect on the $\mathrm{Cl}^{-}, \mathrm{HCO}_{3}^{-}$-ATPase Activity}

We showed earlier that the multifunctional ATPase complex is the enzyme system, including "basal" $\mathrm{Mg}^{2+}$ ATPase, which is stimulated by anions and regulated (activated/inhibited) by $\mathrm{GABA}_{\mathrm{A}}$-ergic ligands. In the samples of plasma membrane from rat brain studied by us, the activity of the "basal" $\mathrm{Mg}^{2+}$-ATPase is $8.8 \mu \mathrm{mol}$ $\mathrm{P}_{\mathrm{i}} / \mathrm{h} / \mathrm{mg}$ protein. This ATPase activity is stimulated by ions $10 \mathrm{mM} \mathrm{Cl}^{-} / 2 \mathrm{mM} \mathrm{HCO}_{3}^{-}$, the stimulation effect $\left(\mathrm{Cl}^{-}\right.$, $\mathrm{HCO}_{3}^{-}$-ATPase activity) is $2.4 \mu \mathrm{mol} \mathrm{P}_{\mathrm{i}} / \mathrm{h} / \mathrm{mg}$ protein.

To verify that the enzymatic activity under study is a $\mathrm{GABA}_{\mathrm{A}}$-coupled ATPase, we added $\mathrm{GABA}_{\mathrm{A}}$-ergic ligands (GABA, bicuculline, picrotoxin) to the incubation medium. GABA $(10 \mu \mathrm{M})$ activated the "basal" $\mathrm{Mg}^{2+}$ ATPase, while no $\mathrm{Cl}^{-}, \mathrm{HCO}_{3}^{-}$-ATPase activity could be detected. This effect of the mediator on the enzyme was eliminated by bicuculline $(20 \mu \mathrm{M})$ and picrotoxin $(50 \mu \mathrm{M})$ (Figure 1(a)). These data confirm that the ATPase activity under study belongs to the same enzyme- $\mathrm{GABA}_{\mathrm{A}}$-coupled ATPase complex. Therefore, if in the presence of an activator the activity of the "basal" $\mathrm{Mg}^{2+}$-ATPase achieves high levels when the molecular turnover is maximal, then an additional activation of the enzyme by anions cannot take place.

The literature shows that $\mathrm{Ca}^{2+}$ modulates the activity of the transport ATPase P-type of different cells. In particular, it was shown that EGTA (EDTA) and $\mathrm{Ca}^{2+}$ can modify the neuronal membrane $\mathrm{Na}^{+}, \mathrm{K}^{+}$-ATPase [19] [20]. At the same time, there was observed a change in the activity of both transport P-type ATPases and "total" $\mathrm{Mg}^{2+}$-ATPase or "basal" $\mathrm{Mg}^{2+}$-ATPase that are insensitive to ouabain [21] [22]. Therefore, we investigated the effect of $\mathrm{Ca}^{2+}$ on the "basal" and $\mathrm{Cl}^{-}, \mathrm{HCO}_{3}^{-}$-activated $\mathrm{Mg}^{2+}$-ATPase activities of the neuronal membranes. In our experiments, $\mathrm{Ca}^{2+}(0.01-1 \mathrm{mM})$ was shown to reduce the activity of "basal" $\mathrm{Mg}^{2+}$-ATPase starting from the concentration of $0.05 \mathrm{mM}$ (Figure 1(b)). In the highest studied concentration of $\mathrm{Ca}^{2+}(1 \mathrm{mM})$ the activity of the 

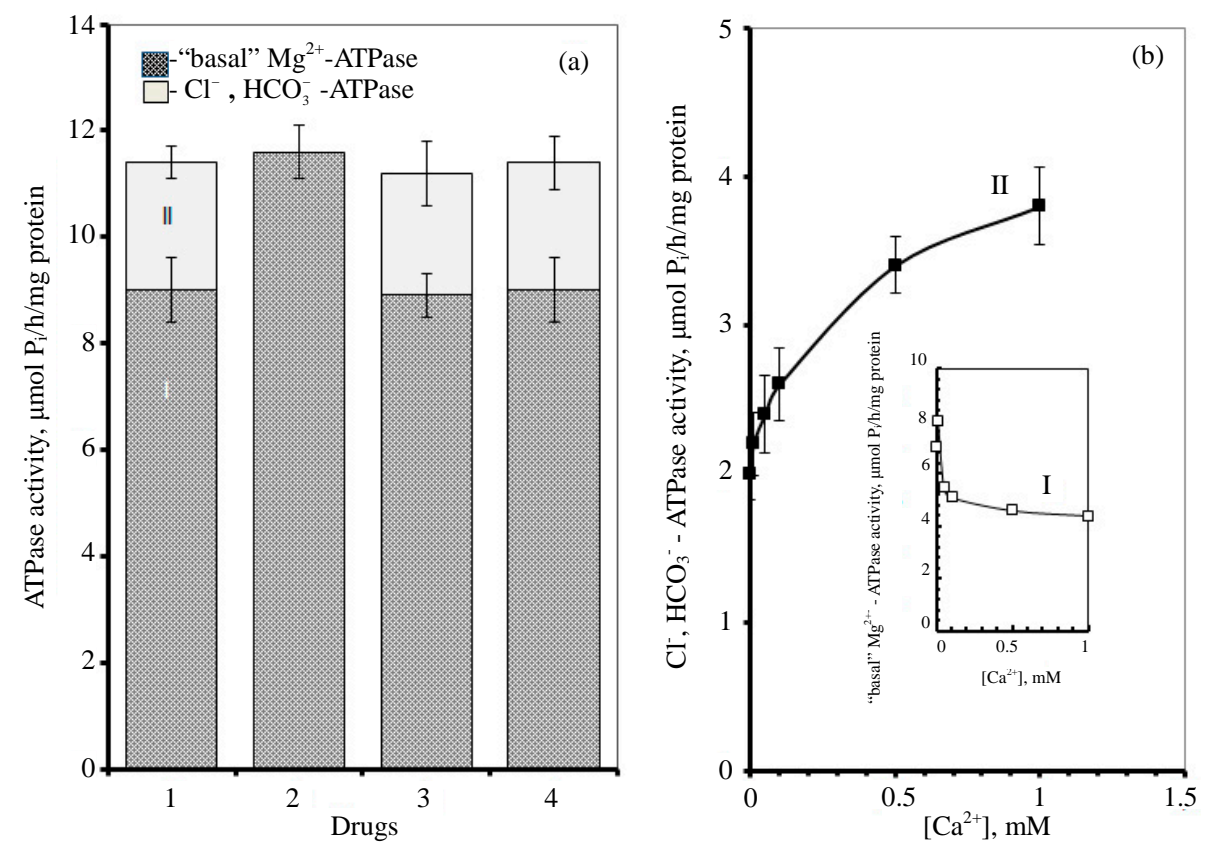

Figure 1. (a) The "basal” (I) and $\mathrm{Cl}^{-}, \mathrm{HCO}_{3}^{-}$-stimulated (II) ATPase activities of rat brain plasma membranes in the absence (1) or in the presence of $10 \mu \mathrm{M}$ GABA (2), $10 \mu \mathrm{M}$ GABA $+20 \mu \mathrm{M}$ bicuculline (3), $10 \mu \mathrm{M}$ GABA $+50 \mu \mathrm{M}$ pirotoxin (4) and (b) The "basal" (I) and $\mathrm{Cl}^{-}, \mathrm{HCO}_{3}^{-}$-stimulated (II) $\mathrm{Mg}^{2+}$-ATPase activities in the presence of the different $\mathrm{Ca}^{2+}$ concentrations. Plasma membrane samples $(20-25 \mu \mathrm{g})$ were added to incubation medium

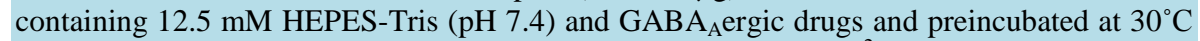
for $20 \mathrm{~min}$. The reaction was started by addition of substrate $\left(\mathrm{Mg}^{2+}\right.$-ATP) in the incubation medium.

"basal” $\mathrm{Mg}^{2+}$-ATPase decreased to $55 \%$ and amounted to $4.4 \mu \mathrm{mol} \mathrm{P}_{\mathrm{i}} / \mathrm{h} / \mathrm{mg}$ protein. Along with this, the $\mathrm{Cl}^{-}$, $\mathrm{HCO}_{3}^{-}$-ATPase activity doubled. In the presence of EGTA $(0.1 \mathrm{mM})$, the activating effect of calcium ions on the enzyme activity does not occur (data not shown). Furthermore, this $\mathrm{Ca}^{2+}$ chelator causes an increase activity of "basal" $\mathrm{Mg}^{2+}$-ATPase by about $17 \%$. These data indicate the presence of free calcium in the incubation medium similar to the literature data. So, in the presence of EDTA (40 $\mu \mathrm{M})$ in the incubation medium, the activity of "basal” $\mathrm{Mg}^{2+}$-ATPase was increased by 65\% [20].

\subsection{Effect of $\mathrm{Ca}^{2+}$ on the ATPase Activity in the Presence of $\mathrm{GABA}_{A}$-Ergic Drugs}

The observed $\mathrm{Ca}^{2+}$ concentrations $(0.5-1 \mathrm{mM})$ that cause the greatest change in the activity of the ATPase under study are similar to concentrations that inhibit the $\mathrm{GABA}_{\mathrm{A}}$-induced $\mathrm{Cl}^{-}$-current. It was shown that intracel-

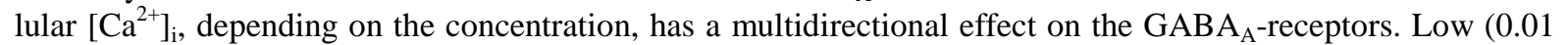
$\mathrm{mM}$ ) concentrations of $\mathrm{Ca}^{2+}$ cause potentiation of the $\mathrm{GABA}_{\mathrm{A}}$-induced $\mathrm{Cl}^{-}$-current, while high $(500 \mu \mathrm{M})$ concentrations reduce their functional activity by decreasing the opening time of the $\mathrm{GABA}_{\mathrm{A}}$-receptor $\mathrm{Cl}^{-}$-channel [13].

Furthermore, it was found that $\left[\mathrm{Ca}^{2+}\right]_{\mathrm{i}}$ accelerates reduction of function (run-down effect) of $\mathrm{GABA}_{\mathrm{A}}$-induced $\mathrm{Cl}^{-}$-current in hippocampal neurons in rats [23] [24]. Therefore, the next step in our work was to study the effect of $\mathrm{Ca}^{2+}$ on the $\mathrm{GABA}_{\mathrm{A}}$-activated $\mathrm{Mg}^{2+}$-ATPase activity (Figure 2). We found that low concentrations of $\mathrm{Ca}^{2+}(0.01 \mu \mathrm{M})$ do not affect this enzymatic activity. At the same time, high concentrations of $\mathrm{Ca}^{2+}(0.25 \mathrm{mM})$ eliminate activation of the "basal" $\mathrm{Mg}^{2+}$-ATPase by GABA.

Bicuculline is known to competitively interact with the allosteric binding site close to the $\mathrm{Cl}^{-}$-channel of the $\mathrm{GABA}_{\mathrm{A}}$ /benzodiazepine receptor complex. This interaction results in a change in the conformation of $\mathrm{Cl}^{-}$channel and reduction of $\mathrm{Cl}^{-}$-conductance in the neuron [24]. The results of our earlier studies showed the func-

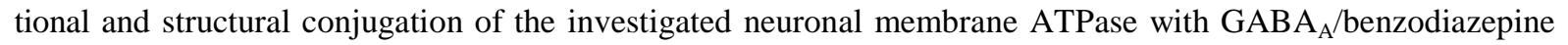




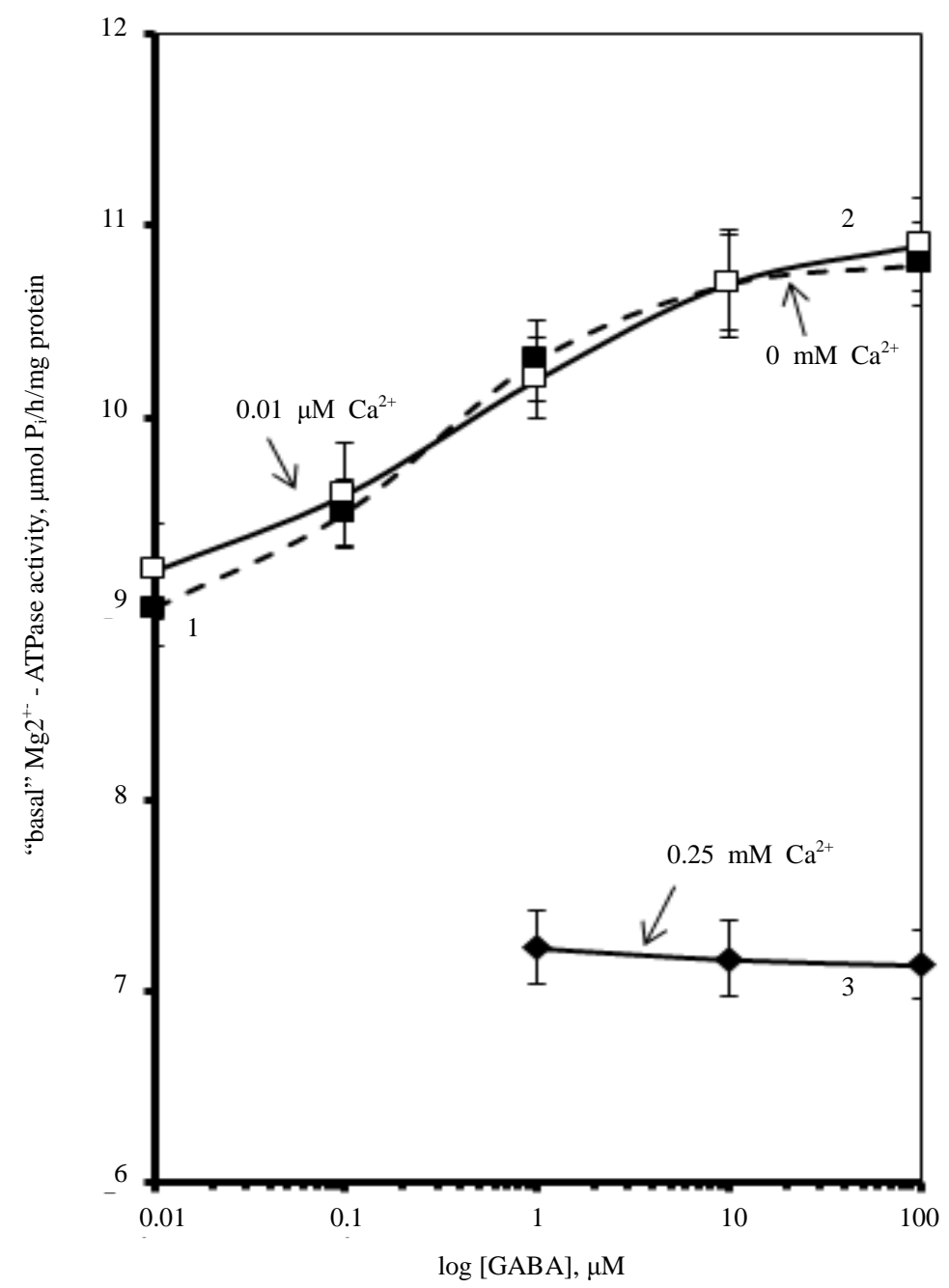

Figure 2. Effect of GABA on the "basal" $\mathrm{Mg}^{2+}$-ATPase activity of rat brain plasma membranes in the absence (1) and in the presence of $0.01 \mu \mathrm{M}(2)$ or $0.25 \mathrm{mM}(3) \mathrm{Ca}^{2+}$ in the incubation medium. Plasma membrane samples (20 $25 \mu \mathrm{g}$ ) were added to incubation medium containing $12.5 \mathrm{mM}$ HEPES-Tris (pH 7.4) and $\mathrm{GABA}_{\mathrm{A}}$-ergic drugs and preincubated at $30^{\circ} \mathrm{C}$ for $20 \mathrm{~min}$. The reaction was started by addition of substrate $\left(\mathrm{Mg}^{2+}-\mathrm{ATP}\right)$ in the incubation medium.

$\mathrm{Cl}^{-}$-channel receptor complex [18]. Therefore, we studied the effect of different concentrations (2.5 - $\left.20 \mu \mathrm{M}\right)$ of bicuculline on the $\mathrm{Cl}^{-}, \mathrm{HCO}_{3}^{-}$-ATPase activity in the absence and in the presence of $\mathrm{Ca}^{2+}$ (Figure 3(a)).

We have found that bicuculline inhibits the investigated activity starting with the concentration of $2.5 \mu \mathrm{M}$, and shows the greatest effect at the concentration of $15 \mu \mathrm{M}$. $\mathrm{Ca}^{2+}(0.25 \mathrm{mM})$ eliminates the inhibitory effect of bicuculline on the $\mathrm{Cl}^{-}$, $\mathrm{HCO}_{3}^{-}$-ATPase activity.

These data suggest that $\mathrm{Ca}^{2+}$ has protective properties against the action of the $\mathrm{GABA}_{\mathrm{A}}$-receptor blocker on the enzyme. In this regard, it seemed appropriate to investigate the effect of different concentrations of $\mathrm{Ca}^{2+}$ (0.01-1 mM) on the $\mathrm{Cl}^{-}, \mathrm{HCO}_{3}^{-}$-ATPase activity in the presence of bicuculline $(20 \mu \mathrm{M})$. It was found that $\mathrm{Ca}^{2+}$ eliminates the inhibitory effect of bicuculline on the ATPase activity starting from $50 \mu \mathrm{M}$ (Figure 3(b)). The greatest increase of the effect of calcium cations is observed in the concentration range of $0.1-0.5 \mathrm{mM}$.

\subsection{Role of Phosphatases on Modulation of the ATPase Activity by $\mathrm{Ca}^{2+}$}

It is known from the literature that the function of the $\mathrm{GABA}_{\mathrm{A}}$-receptors is supported by processes of 

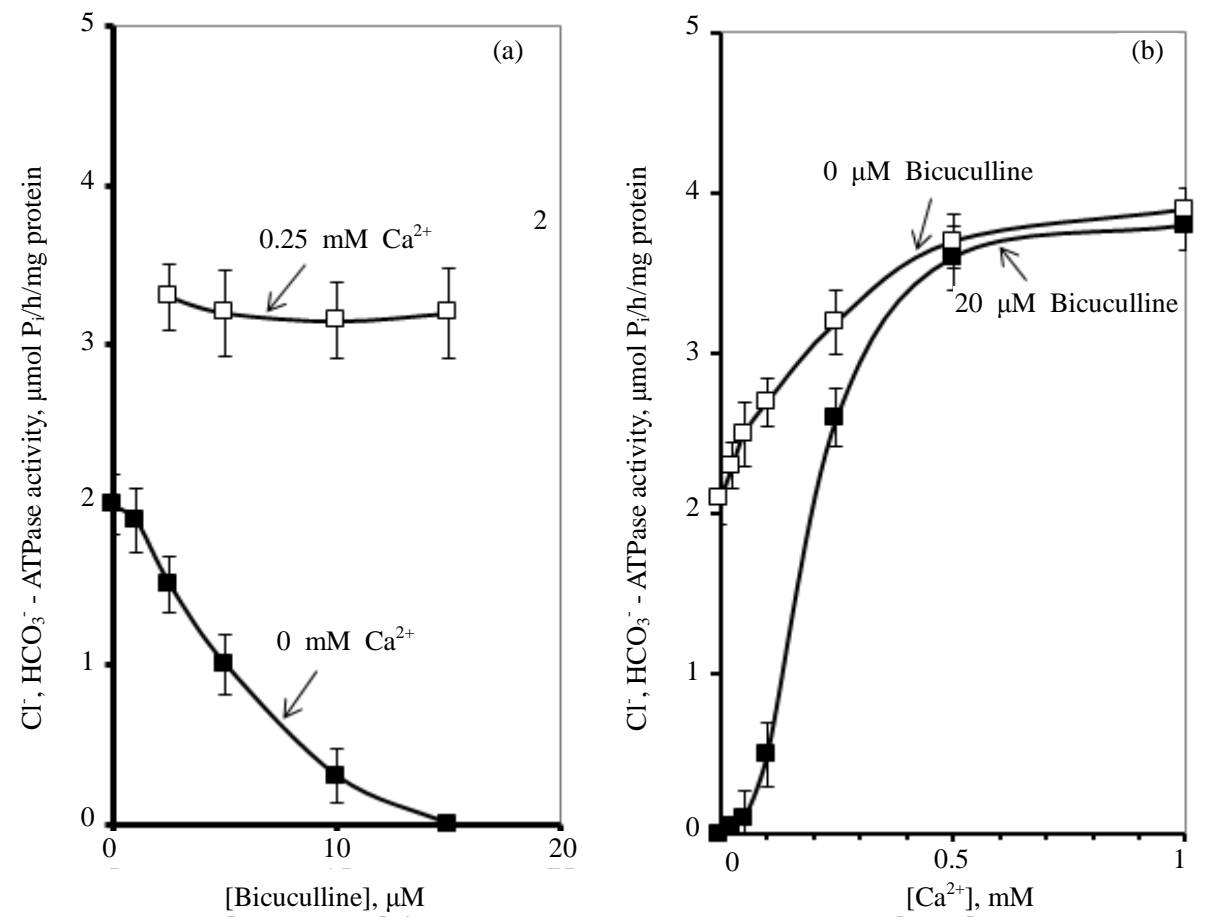

Figure 3. Effect of bicuculline (a) or calcium (b) on the $\mathrm{Cl}^{-}, \mathrm{HCO}_{3}^{-}$-stimulated ATPase activity of rat brain plasma membranes in the absence and in the presence of $\mathrm{Ca}^{2+}$ or bicuculline, respectively. Plasma membrane samples (20 - $25 \mu \mathrm{g})$ were added to incubation medium containing $12.5 \mathrm{mM}$ HEPES-Tris (pH 7.4) and GABA $\mathrm{A}_{\mathrm{A}}$ ergic drugs and preincubated at $30^{\circ} \mathrm{C}$ for $20 \mathrm{~min}$. The reaction was started by addition of substrate $\left(\mathrm{Mg}^{2+}-\mathrm{ATP}\right)$ in the incubation medium.

phosphorylation of receptor molecule or tightly bound regulatory molecules [13] [25] [26]. In the developed nervous system a high activity of protein tyrosine kinases and protein tyrosine phosphatases was shown, suggesting that protein tyrosine phosphorylation is an important factor for neuronal function. It has been shown that inhibitors of these enzymes regulate the functional activity of receptors involved in excitatory and inhibitory processes [10]. Thus, $o$-vanadate, blocker of protein phosphatases and transport ATPases P-type, increased the effect of GABA on the $\mathrm{GABA}_{\mathrm{A}}$-receptors. Genistein and tyrphostin, blockers of protein tyrosine kinases, inhibited the $\mathrm{GABA}_{\mathrm{A}}$-induced accumulation of ${ }^{36} \mathrm{Cl}$ by brain membrane vesicles in mice, and $\mathrm{GABA}_{\mathrm{A}}$-induced $\mathrm{Cl}^{-}$-current in brain neuronal membranes in rats [27] [28]. These data suggest an important role of these enzymes in the maintenance of $\mathrm{GABA}_{\mathrm{A}}$-receptor function. In our study, $o$-vanadate $(0.1 \mathrm{mM})$ reduces the $\mathrm{GABA}_{\mathrm{A}}$-induced $\mathrm{Mg}^{2+}$-ATPase activity. At the same time, genistein $(0.1 \mathrm{mM})$ has no effect on this ATPase activity.

To investigate the possible involvement of these phosphatases in the action of $\mathrm{Ca}^{2+}$ on the investigated ATPase, we added $o$-vanadate and $\mathrm{Ca}^{2+}$ to the incubation medium (Figure 4). It was found that independent action of each of the two substances reduces the "basal" $\mathrm{Mg}^{2+}$-ATPase and increases the $\mathrm{Cl}^{-}, \mathrm{HCO}_{3}^{-}$-ATPase activity. The combined action of these substances does not result in the increase of their inhibitory effect on the "basal" $\mathrm{Mg}^{2+}$-ATPase activity. These results are in a good agreement with the data obtained in the study of vanadatesensitive alkaline phosphatase conjugated with $\mathrm{GABA}_{\mathrm{A}}$-receptors [13]. Its role in the regulation of the $\mathrm{GABA}_{\mathrm{A}^{-}}$ receptor function was confirmed by addition of the enzyme to intracellular perfusate, which caused complete decline (run-down effect) of their function. Inhibition of such phosphatase by $o$-vanadate induced recovery of the $\mathrm{GABA}_{\mathrm{A}}$-receptor function [10] [27] [28].

Previously, Hyden and colleagues showed the existence on rabbit Deiters' neuron membrane of molecular (protein) machineries which recognize intracellular GABA and extrude chloride [29]. It was suggested that these structures are devices that at the expense of ATP consumed in their phosphorylation, extrude $\mathrm{Cl}^{-}$after postsynaptic GABA uptake into the Deiters' neurons. The GABA effect was blocked by classical $\mathrm{GABA}_{\mathrm{A}}$ antagonists picrotoxin $(100 \mu \mathrm{M})$ and bicuculline $(10 \mu \mathrm{M})$ and also activated in a biphasic manner by pentobarbitone. Such 

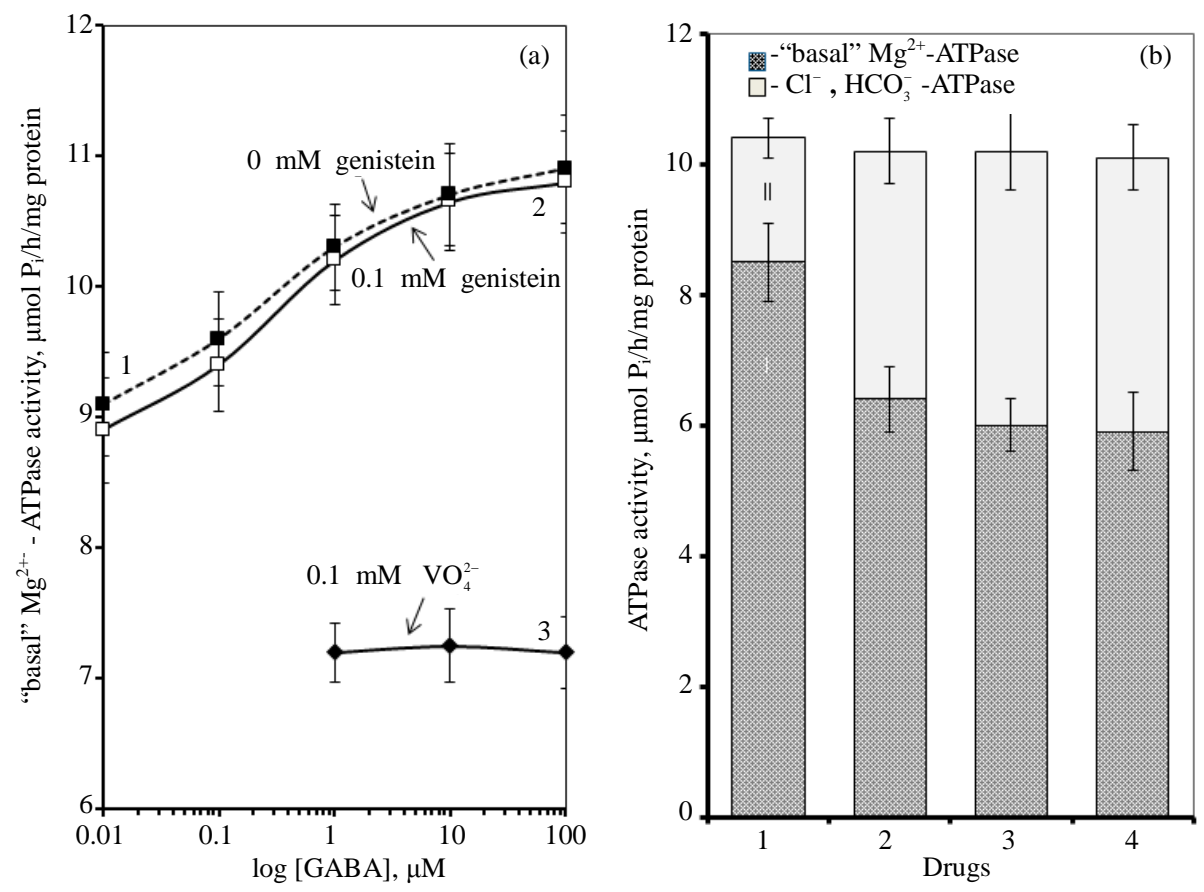

Figure 4. (a) Effect of GABA on the "basal» $\mathrm{Mg}^{2+}$-ATPase activity of rat brain plasma membranes in the absence (1) and in the presence of $0.1 \mathrm{mM}$ genistein (2) or $0.1 \mathrm{mM}$ $o$-vanadate (3); (b) The "basal" (I) and $\mathrm{Cl}^{-}, \mathrm{HCO}_{3}^{-}$-stimulated (II) ATPase activities of the neuronal membrane in the absence (1) and in the presence $0.25 \mathrm{mM} \mathrm{Ca}^{2+}$ (2), $0.1 \mathrm{mM}$ $o$-vanadate (3) and $0.25 \mathrm{mM} \mathrm{Ca}^{2+}+0.1 \mathrm{mM} o$-vanadate (4). Plasma membrane samples (20 $25 \mu \mathrm{g}$ ) were added to incubation medium containing $12.5 \mathrm{mM}$ HEPES-Tris (pH 7.4) and $\mathrm{GABA}_{\mathrm{A}}$ ergic drugs and preincubated at $30^{\circ} \mathrm{C}$ for $20 \mathrm{~min}$. The reaction was started by addition of substrate $\left(\mathrm{Mg}^{2+}-\mathrm{ATP}\right)$ in the incubation medium.

properties have suggested to these authors that these receptors are $\mathrm{GABA}_{\mathrm{A}}$-activated $\mathrm{Cl}^{-}$-pumps, where the energy for chloride extrusion is provided by ATP in a phosphorylation step within the extrusion cycle. The core mechanism is the inversion of two energy peaks along the permeation pathway. However, the role of ATP in the phosphorylation step of $\mathrm{GABA}_{\mathrm{A}}$-regulated $\mathrm{Cl}^{-}$-pump is not conclusively established.

Analogously, the results of this work and preliminary our studies have shown that the investigated ATPase was inhibited by picrotoxin (or bicuculline) and regulated by modulators (anticonvulsants, benzodiazepines, anesthetics) [18]. Our biochemical and cytochemical findings enabled us postulating a new model of activity of the multifunctional ATPase complex-an enzyme that is also a $\mathrm{Cl}^{-}$-pump and a receptor. We propose that the ATPase complex is closely related to $\mathrm{GABA}_{\mathrm{A}}$-receptor and therefore can exist either in a phosphorylated ATPase complex-P (first functional state) or dephosphorylated form (second functional state). The former case has a low "basal" $\mathrm{Mg}^{2+}$-ATPase activity and it is activated by $\mathrm{Cl}^{-} / \mathrm{HCO}_{3}^{-}$ions. This state enables the protein to participate in the ATP-dependent transport of anions. Phosphorylation is opposed by a dephosphorylation process which renders the ATPase complex as nonfunctional (the enzyme cannot participate in the ATP-dependent transport of anions). In this case, it has a high "basal" $\mathrm{Mg}^{2+}$-ATPase activity and it is not activated by anions. The dephosphorylation process is catalyzed by a vanadate-sensitive phosphatase. Thus, with the provision of $\mathrm{Mg}^{2+}$-ATP, a protein kinase (or directly ATP) phosphorylates the molecular complex and maintains the ATPase functional form. A similar cycle has been suggested to play a role in the regulation of $\mathrm{GABA}_{\mathrm{A}}$-receptor [28] and $\mathrm{GABA}_{\mathrm{A}}$-activated $\mathrm{Cl}^{-}$-pump. Yet, our results demonstrates that after convulsant effect, the dephosphorylation of the enzyme also occurs. As a result the ATPase doesn't participate in the chloride transport (as the "collapsed" state). Our results suggest that not only inhibitors (o-vanadate, genistein, convulsants) have effect on the phosphatase activity, but also $\mathrm{Ca}^{2+}$ ions have an influence on the enzyme activity, as a result of their effect on the state of the protein phosphorylation.

Cations of calcium play a vital role in the function of cells of various origin (including neurons). The concen- 
tration gradient of calcium across the plasma membrane of neuronal cells is a very high, from $\sim 10^{-3} \mathrm{M} \mathrm{Ca}^{2+}$ outside, to $\sim 10^{-7} \mathrm{M} \mathrm{Ca}^{2+}$ inside [30]. The free calcium concentration in neurons is supported by various mechanisms (buffering systems, compartmentation and extrusion from the neuronal cells). In earlier studies it was shown that $\mathrm{Ca}^{2+}(1-5 \mathrm{mM})$ decreased the number of GABA binding sites in rat cortical synaptic membranes [14]. Increases in $\left[\mathrm{Ca}^{2+}\right]_{\mathrm{i}}(>1 \mu \mathrm{M})$ were reported in some works to reduce the open time [31] or to cause depression [23] of $\mathrm{GABA}_{\mathrm{A}}$-activated $\mathrm{Cl}^{-}$-channels in pituitary cells and dentate granule cells, respectively. In contrast, maintenance of a low level of $\left[\mathrm{Ca}^{2+}\right]_{\mathrm{i}}(<0.1 \mu \mathrm{M})$ was required for full activation of $\mathrm{GABA}_{\mathrm{A}}$-induced $\mathrm{Cl}^{-}$-current in guinea pig hippocampal neurons [32]. An increased intracellular $\mathrm{Ca}^{2+}$ concentration $(10 \mathrm{nM}-34 \mu \mathrm{M})$ caused a transient augmentation of the $\mathrm{GABA}_{\mathrm{A}}$-induced $\mathrm{Cl}^{-}$-current [15]. Moreover, it was established, that $\mathrm{Ca}^{2+}$ (depending on the concentration) has a biphasic effect on synaptic $\mathrm{GABA}_{\mathrm{A}}$ receptor $\mathrm{Cl}^{-}$-channel [23]. So, the amplitude of $\mathrm{GABA}_{\mathrm{A}}$-induced $\mathrm{Cl}^{-}$-current recorded with $1 \mathrm{mM}$ internal $\mathrm{CaCl}_{2}$ and $10 \mathrm{mM}$ EGTA (10 nM free $\mathrm{Ca}^{2+}$ ) decayed by less than $30 \%$ of control. At the same time, increasing the $\mathrm{CaCl}_{2}$ concentration to $10 \mathrm{mM}$ (34 $\mu \mathrm{M}$ free $\mathrm{Ca}^{2+}$ ) induced a transient potentiation of the $\mathrm{GABA}_{\mathrm{A}}$-current [33].

Calcium has been shown to exert a powerful inhibitory effect on the $\mathrm{Na}^{+}, \mathrm{K}^{+}$-ATPase of cell membranes [19] [34]. In particular, it was shown that in the presence of EDTA, $\mathrm{Ca}^{2+}\left(10^{-6}-3 \times 10^{-3} \mathrm{M}\right)$ always exerts an inhibitory effect on the $\mathrm{Na}^{+}, \mathrm{K}^{+}$-ATPase [34]. Addition of $\mathrm{Ca}^{2+}$ to the incubation medium in the absence of EDTA caused no change in the "basal" $\mathrm{Mg}^{2+}$-ATPase activity at $>10^{-3} \mathrm{M} \mathrm{Ca}^{2+}$. However at low $(1-3 \mu \mathrm{M}) \mathrm{Ca}^{2+}$ in the media there was a significant stimulation of the $\mathrm{Na}^{+}, \mathrm{K}^{+}$-ATPase activity and decreasing as $\mathrm{Ca}^{2+}$ increased. So, at $10^{-3} \mathrm{M} \mathrm{Ca}^{2+}$ in the incubation medium an inhibition by $61 \%$ of the $\mathrm{Na}^{+}, \mathrm{K}^{+}$-ATPase activity occurred. Calcium concentrations that affect $\mathrm{Na}^{+}, \mathrm{K}^{+}$-ATPase are similar to concentrations that are effective on the ATPase we studied here. In our study, $\mathrm{Ca}^{2+}(>50 \mu \mathrm{M})$ inhibits the activity of basal $\mathrm{Mg}^{2+}$-ATPase and greatly increases the $\mathrm{Cl}^{-}, \mathrm{HCO}_{3}^{-}$-ATPase activity. However the effects seen at millimolar $\mathrm{Ca}^{2+}$ levels may not be seen in the cell except, perhaps, transiently.

Our data demonstrate, for the first time, the sensitivity of the investigated multifunctional ATPase complex to calcium cations. This conclusion is well demonstrated by our results on reduction of the activity of "basal" $\mathrm{Mg}^{2+}$-ATPase and stimulation of the $\mathrm{Cl}^{-}, \mathrm{HCO}_{3}^{-}$-ATPase activity with the increase of $\mathrm{Ca}^{2+}$ concentration in the incubation medium. Interdependent multidirectional response of these two ATPase activities to change in concentration of $\mathrm{Ca}^{2+}$ confirms the conjugation between investigated enzymes, and their association to the same complex. Furthermore, it indicates their involvement in $\mathrm{Ca}^{2+}$-dependent processes. This is confirmed by the results of the study of the effect of $\mathrm{Ca}^{2+}$ on the "basal" and $\mathrm{Cl}^{-}, \mathrm{HCO}_{3}^{-}$-activated $\mathrm{Mg}^{2+}$-ATPase activities in the presence of $\mathrm{GABA}_{\mathrm{A}}$-ergic ligands, which are presented in this paper and in earlier studies. They also show a multidirectional GABA $\mathrm{A}_{\mathrm{A}}$-regulation of the ATPase activity. These data are in good agreement with the published data on the effect of $\mathrm{Ca}^{2+}$ on the functional activity of the $\mathrm{GABA}_{\mathrm{A}}$-receptors [14] [15]. The authors demonstrated that $\mathrm{GABA}_{\mathrm{A}}$-receptor activity varies depending on intracellular cation concentration. Moreover, $\mathrm{Ca}^{2+}$ can interact directly with the receptors either through binding sites on the molecule, or through receptor-conjugated enzyme systems (in particular $\mathrm{Ca}^{2+} /$ calmodulin-dependent protein phosphatase, or via $\mathrm{Ca}^{2+}$-dependent protein kinase). In our study, the conjugation of the investigated ATPase activities and their involvement in $\mathrm{Ca}^{2+}$-dependent processes is also demonstrated by the effect of protein tyrosine phosphatase and protein tyrosine kinase blockers. Specifically, we have shown that the GABA-induced $\mathrm{Cl}^{-}$-ATPase activity is not sensitive to $o$-vanadate blocker but is inhibited by genistein blocker [35]. In contrast, in this work, $o$-vanadate in the absence of $\mathrm{Ca}^{2+}$ inhibited the $\mathrm{GABA}_{\mathrm{A}}$-induced "basal" $\mathrm{Mg}^{2+}$-ATPase activity, and genistein did not affect the effect of the GABA on the enzyme. Therefore, although the "basal" and $\mathrm{Cl}^{-}, \mathrm{HCO}_{3}^{-}$-activated $\mathrm{Mg}^{2+}$-ATPase activities are structurally conjugated, their functional activities can be dissociated by means of blockers of $\mathrm{Ca}^{2+}$-dependent protein kinases and protein phosphatases. This process can involve $\mathrm{GABA}_{\mathrm{A}}$ ergic ligands.

In this paper, we have found that in the presence of $\mathrm{Ca}^{2+}$ in the incubation medium, no effect of bicuculline on the $\mathrm{Cl}^{-}, \mathrm{HCO}_{3}^{-}$-ATPase activity could be observed. Based on these data, it can be concluded that $\mathrm{Ca}^{2+}$ plays an ATPase-protective role. In therapeutic practice bicuculline is known as a convulsant. Therefore, our results can be important in the study of mechanisms of epileptogenesis, which are caused by various neurological or systemic disorders. This largely relates to electrolyte imbalance, especially calcium and magnesium imbalance. In particular, abnormalities of $\mathrm{Ca}^{2+}$ homeostasis can affect the neuromuscular excitability, forming convulsive readiness in the brain, and hypocalcemia is often a side effect of anticonvulsant treatment [11]. In most cases, patients with epilepsy have hypocalcemia and hypomagnesemia [36] [37]. Our results on the protective role of $\mathrm{Ca}^{2+}$ for multifunctional ATPase during the action of convulsants suggest the use of these cations in the investi- 
gation of their anticonvulsive therapeutic effect in experiments in vivo.

\section{Conclusion}

This study provides an additional biochemical characterization of multifunctional ATPase. Furthermore, cations of calcium regulate the ATPase activity in the absence of drugs. Consequently, the modulation of the multifunctional ATPase activity by $\mathrm{GABA}_{\mathrm{A}}$-ergic drugs is a $\mathrm{Ca}^{2+}$-dependent process. It is important to understand the basic properties of this new multifunctional ATPase system and how it responds to changes in its environment. The obtained results seem to have an important functional significance in the study of the mechanisms of epileptogenesis and convulsant-induced seizure activity.

\section{References}

[1] Gerencser, G.A. and Zhang, J. L. (2003) Chloride ATPase Pumps in Nature: Do They Exist? Biological Reviews, 78, 197-218. http://dx.doi.org/10.1017/S146479310200605X

[2] Inagaki, C., Hara, M. and Zeng, X.T. (1996) $\mathrm{A} \mathrm{Cl}^{-}$-Pump in Rat-Brain Neurons. Journal of Experimental Zoology, 275, 262-268.

[3] Menzikov, S.A. and Menzikova, O.V. (2007) Comparative Properties of Sensitive to $\mathrm{GABA}_{\mathrm{A}}$-Ergic Ligands, $\mathrm{Cl}^{-}$, $\mathrm{HCO}_{3}^{-}$-Activated $\mathrm{Mg}^{2+}$-ATPase from Brain Plasma Membranes of Fish and Rats. Zhurnal Evoliutsionnoi Biokhimii Fiziologii, 43, 246-253.

[4] Bormann, J., Hamill, O.P. and Sakmann, B. (1987) Mechanism of Anion Permeation through Channels Gated by Glycine and Gamma-Aminobutyric Acid in Mouse Cultured Spinal Neurones. Journal of Physiology (London), 385, 243286.

[5] Menzikov, S.A., Ruzhinskaia, N.N. and Menzikova, O.V. (2000) $\mathrm{Mg}^{2+}$-ATPase in the Fish Brain and Its Ultrastructural Localization. Zhurnal Evoliutsionnoi Biokhimii Fiziologii, 36, 263-267.

[6] Menzikov, S.A., Karpova, M.N. and Kalinina, M.V. (2011) Effect of $\mathrm{HCO}_{3}^{-}$Ions on the ATP-Dependent GABA Receptor-Coupled $\mathrm{Cl}^{-}$Channel in Rat Brain Plasma Membranes. Bulletin of Experimental Biology and Medicine, 152, 38-42. http://dx.doi.org/10.1007/s10517-011-1448-z

[7] Menzikov, S.A. and Menzikova, O.V. (2006) Phosphorylation of $\mathrm{Cl}^{-}, \mathrm{HCO}_{3}{ }^{-}$-Stimulated $\mathrm{Mg}^{2+}$-ATPase of Plasma Membranes of Carp (Cyprinus carpio L.) Brain Sensitive to $\mathrm{GABA}_{\mathrm{A}}$-Ergic Ligands. Ukrainskii Biokhimicheskii Zhurnal, 78, 63-69.

[8] Menzikov, S.A., Karpova, M.N. and Kalinina, M.V. (2012) Effect of Pentylenetetrazole on the $\mathrm{GABA}_{\mathrm{A}}-\mathrm{Coupled} \mathrm{Cl}^{-}$, $\mathrm{HCO}_{3}{ }^{-}$-Activated $\mathrm{Mg}^{2+}$-ATPase Activity of the Plasma Membrane from Rat Brain Both in Vitro and in Vivo Experiences. Pathological Physiology and Experimental Therapy, 98-102.

[9] Walton, N.Y., Nagy, A.K. and Treiman, D.M. (1998) Altered Residual ATP Content in Rat Brain Cortex Subcellular Fractions following Status Epilepticus Induced by Lithium and Pilocarpine. Journal of Molecular Neuroscience, 11, 233-242. http://dx.doi.org/10.1385/JMN:11:3:233

[10] Palma, E., Ragozzino, D.A., Angelantonio, S., Spinelli, Di G., Trettel, F., Martinez-Torres, A., Torchia, G., Arcella, A., Gennaro, G. Di., Quarato, P.P., Esposito, V., Cantore, G., Miledi, R. and Eusebi, F. (2004) Phosphatase Inhibitors Remove the Run-Down of Gamma-Aminobutyric Acid Type A Receptors in the Human Epileptic Brain. Proceedings of the National Academy of Sciences of the USA, 101, 10183-10188. http://dx.doi.org/10.1073/pnas.0403683101

[11] Kotova, S.M., Zasedateleva, I.Yu. and Koroleva, N.Yu. (2005) Peculiarities of Mineral Metabolism in Patients with Epilepsy. Journal of Neurology and Psychiatry (Russia), 3, 70-71.

[12] Cupello, A., Hyden, H., Rapallino, M.V. and Robello, M. (1998) Regulation by Intracellular Calcium of the Activity of $\mathrm{GABA}_{\mathrm{A}}$ Receptors in Two Different Types of Neurons. Neural Circuits and Networks NATO ASI Series, 167, 53-69.

[13] Chen, Q.X., Stelzer, A., Kay, A.R. and Wong, R.K. (1990) GABA A Receptor Function Is Regulated by Phosphorylation in Acutely Dissociated Guinea-Pig Hippocampal Neurons. The Journal of Physiology, 420, 207-221.

[14] Corda, M.G. and Guidotti, A. (1983) Modulation of GABA Receptor Binding by Ca ${ }^{2+}$. Journal of Neurochemistry, 41, 277-280. http://dx.doi.org/10.1111/j.1471-4159.1983.tb11840.x

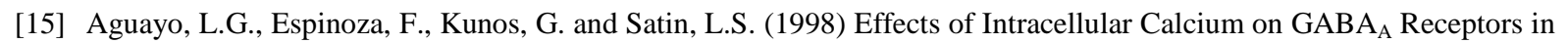
Mouse Cortical Neurons. Pflugers Archiv, 435, 382-387. http://dx.doi.org/10.1007/s004240050527

[16] Chen, P.S., Toribara, T.Y. and Warner, H. (1990) Microdetermination of Phosphorus. Analytical Chemistry, 28, 17561758. http://dx.doi.org/10.1021/ac60119a033

[17] Bradford, M.M. (1976) A Rapid and Sensitive Method for the Quantitation of Microgram Quantities of Protein Utilizing the Principal of Protein-Dye Binding. Analytical Biochemistry, 72, 248-254. 
http://dx.doi.org/10.1016/0003-2697(76)90527-3

[18] Menzikov, S.A. (2013) Neuronal Multifunctional ATPase. Biophysical Reviews and Letters, 8, 213-227. http://dx.doi.org/10.1142/S1793048013300065

[19] Yingst, D.R. (1988) Modulation of the Na, K-ATPase by Ca and Intracellular Proteins. Annual Review of Physiology, 50, 291-303. http://dx.doi.org/10.1146/annurev.ph.50.030188.001451

[20] Powis, D.A. and Wattus, G.D. (1981) The Stimulatory Effect of Calcium on Na, K-ATPase of Nervous Tissue. FEBS Letters, 126, 285-288. http://dx.doi.org/10.1016/0014-5793(81)80262-1

[21] Tsakiris, S., Koromilas, C. and Schulpis, K.H. (2001) Reduced $\mathrm{Mg}^{2+}$-ATPase Activity in the Hypoglycemic Adult Rat Brain. Zeitschrift fur Naturforschung C-A. Journal of Biosciences, 56, 912-914.

[22] Vasic, V., Jovanović, D., Krstić, D., Nikezić, G., Horvat, A., Vujisić, L., et al. (1999) Prevention and Recovery of $\mathrm{CuSO}_{4}$-Induced Inhibition of $\mathrm{Na}^{+} / \mathrm{K}^{+}$-ATPase and $\mathrm{Mg}^{2+}$-ATPase in Rat Brain Synaptosomes by EDTA. Toxicology Letters, 110, 95-103. http://dx.doi.org/10.1016/S0378-4274(99)00144-7

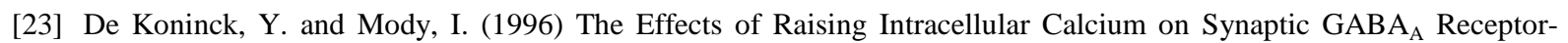
Channels. Neuropharmacology, 35, 1365-1374. http://dx.doi.org/10.1016/S0028-3908(96)00063-9

[24] Li, L., Wang, Y., Ma, K.T., Cheng, H.J., Zhao, L. and Si, J.Q. (2013) The Effect of Niflumic Acid and Blocker of Calcium Channel on the Desensitization of Gamma Aminobutyric Acid-Activated Current. Zhongguo Ying Yong Sheng Li Xue Za Zhi, 29, 128-132.

[25] Obrietan, K. and van den Pol, A.N. (1995) GABA Neurotransmission in the Hypothalamus: Developmental Reversal from $\mathrm{Ca}^{2+}$ Elevating to Depressing. The Journal of Neuroscience, 7, 5065-5077.

[26] Akopian, A., Gabriel, R. and Witkovsky, P. (1998) Calcium Released from Intracellular Stores Inhibits GABA A-Me- $^{-}$ diated Currents in Ganglion Cells of the Turtle Retina. Journal of Neurophysiology, 80, 1105-1115.

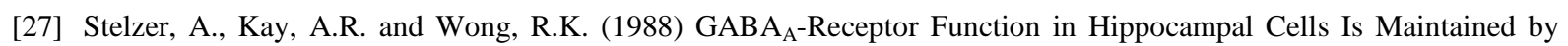
Phosphorylation Factors. Science, 241, 339-341. http://dx.doi.org/10.1126/science.2455347

[28] Jassar, B.S., Ostashewski, P.M. and Jhamandas, J.H. (1997) GABA Receptor Modulation by Protein Tyrosine Kinase in the Rat Diagonal Band of Broca. Brain Research, 775, 127-133. http://dx.doi.org/10.1016/S0006-8993(97)00892-5

[29] Hydén, H., Rapallino, M.V. and Cupello, A. (2000) Unraveling of Important Neurobiological Mechanisms by the Use of Pure, Fully Differentiated Neurons Obtained from Adult Animals. Progress in Neurobiology, 60, 471-499. http://dx.doi.org/10.1016/S0301-0082(99)00035-0

[30] Simons, T.J. (1988) Calcium and Neuronal Function. Neurosurgical Review, 11, 119-129. http://dx.doi.org/10.1007/BF01794675

[31] Taleb, O., Trouslard. J., Demeneix, B.A., Feltz, P., Bossu, J.L., Dupont, J.L. and Feltz, A. (1987) Spontaneous and GABA-Evoked Chloride Channels on Pituitary Intermediate Lobe Cells and Their Internal Ca Requirements. Pflügers Archiv, 409, 620-631. http://dx.doi.org/10.1007/BF00584663

[32] Stelzer, A., and Wong, R.K. (1987) GABA Receptors of Isolated Guinea-Pig Hippocampal Neurons: Intra- and Extracellular Regulatory Factors. The Journal of Physiology (London), 394, 115-120.

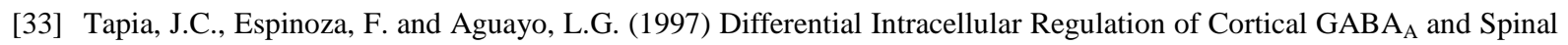
Glycine Receptors in Cultured Neurons. Brain Research, 769, 203-210. http://dx.doi.org/10.1016/S0006-8993(97)00672-0

[34] Abashidze, S., Jariashvili, T. and Kometiani, Z. (2001) The Effect of EGTA and Ca ${ }^{++}$in Regulation of the Brain Na/KATP-ase by Noradrenaline. BMC Biochemistry, 2, 8. http://dx.doi.org/10.1186/1471-2091-2-8

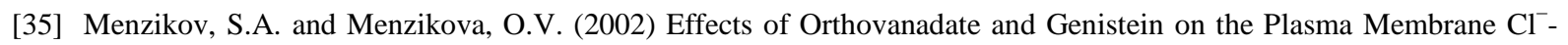
ATPase Sensitive to $\mathrm{GABA}_{\mathrm{A}}$-Ergic Ligands in the Bream (Abramis brama L.) Brain. Doklady Biological Sciences, 385 , 334-336. http://dx.doi.org/10.1023/A:1019952515746

[36] Farhat, G., Yamout, B., Mikati, M.A., Demirjian, S., Sawaya, R. and Fuleihan, G.E.H. (2002) Effect of Antiepileptic Drugs on Bone Density in Ambulatory Patients. Neurology, 58, 1348-1353. http://dx.doi.org/10.1212/WNL.58.9.1348

[37] Cesur, Y., Yuca, S.A., Kaya, A., Yilmaz, C. and Bay, A. (2013) Vitamin D deficiency Rickets in Infants Presenting with Hypocalcaemic Convulsions. West Indian Medical Journal, 62, 201-204. 